\title{
Pollination ecology of Clerodendrum indicum (Lamiaceae): first report of deceit pollination by anther-mimicking stigma in a bisexual flower
}

\author{
Arijit Ghosh \& Pankaj K. Pal* \\ Palaeobotany and Palynology Section, Botany Department, Burdwan University, Burdwan, West Bengal, \\ India - 713 104; arijit.botany@gmail.com; pkpalbot@gmail.com* \\ * Correspondence
}

Received 14-VII-2016. Corrected 02-V-2017. Accepted 01-VI-2017.

\begin{abstract}
Clerodendrum indicum (Lamiaceae) is a medicinally important shrub. We have studied the details of its pollination ecology which was hitherto unknown. The work was done during three consecutive years 20122014, based on 118 plants occurring in three widely separated wild populations in West Bengal, India, together with 25 individuals grown in an experimental plot. Details of flower structure and dynamics of floral events, pollen production and pollen dispersal, visitors and pollinators, floral attractants and floral rewards and pollen transfer mechanism have been worked out by standard methodologies with a 10x high resolution hand lens (IRL), a Leica WILD M3B Stereo-binocular microscope (Switzerland) and a Leica DMLB compound bright field light microscope (Germany). The tubular flower of four-day longevity attracts its visitors by visual cues. Flowers are visited regularly by ten species of insects. On the basis of the visitor behaviour, these can be classified into three distinct categories, viz., visitors belonging to Category-I act on cushion and trichome nectaries of calyx and corolla respectively, those of Category-II act on the dehisced anthers and trichome nectaries of corolla while those of Category-III act on dehisced anthers as well as receptive stigma. Majority of the visitors belong to either Category-I or Category-II. They visit only the $2^{\text {nd }}$ day flowers and never visit a $3^{\text {rd }}$ day flower when the stigma assumes receptivity. Therefore, they are not regarded as pollinators but, act as pollen and/or nectar robbers. Those are discriminated by offering secretions from extra-nuptial nectaries of the flower. Visitor species of Category-III, represented by a species of Trigona, constitute the legitimate pollinator of the plant and thereby, making the plant monophilic. Pollen presentation from the bisexual, dichogamous and protandrous flower takes place on the $2^{\text {nd }}$ day, while the stigma assumes its receptivity on the $3^{\text {rd }}$ day of flower opening. Pollen transfer to the body of the pollinator by a $2^{\text {nd }}$ day flower in its male phase is achieved by offering edible pollen grains. On the other hand, a $3^{\text {rd }}$ day flower at its female phase is devoid of the reward (pollen grain). The yellow shiny receptive stigma of such a flower strikingly mimics the freshly dehisced anthers and the pollinators being lured by such a stigma inadvertently transfer pollen onto it. C. indicum is so far the only known species of flowering plants where deceit pollination occurs by anther-mimicking stigma in a bisexual flower. Rev. Biol. Trop. 65 (3): 988-1001. Epub 2017 September 01.
\end{abstract}

Key words: dichogamy, protandry, monophily, Trigona.

Successful pollination in flowering plants is critical for the production of sexually derived propagules and therefore, is an important priority for continuation of a species through time in changing environments. The transfer of pollen from an anther of a flower to a conspecific stigma is mediated by various biotic and abiotic agents. Zoophilous flowers produce attractants and rewards to ensure repeated pollinator visitation. Pollinator attraction is generally achieved through visual or olfactory cues, whereas the pollen transfer is usually accomplished by offering rewards that satisfy physiological needs of the pollinators, 
in terms of food, shelter and brood-site (Faegri \& van der Pijl, 1979). However, pollinators are not always rewarded by the flowers. Less frequently, there are species in which pollinators are attracted by a false display of reward. Flowers of such plants deceitfully attract their pollinators by mimicking the structures of rewarding flowers or organs (Faegri \& van der Pijl, 1979). Deceit pollination is perhaps one of the extreme examples of utilization of services of animals by plants without offering any benefit (Renner, 2006). Sprengel, in as early as 1793 , was the first to report such deceitful pollination based on his observations on two species of the genus Orchis, O. latifolia and $O$. morio. Subsequently, pollination by deceit have been reported from time to time in a number of unrelated taxa, viz. Amborella trichopoda (Thien et al., 2003), Schisandra henryi (Yuan et al., 2007), Schisandra sphenanthera (Du, Huang, \& Wang, 2012), Orchis israelitica (Galizia et al., 2005), Commelina benghalensis and Commelina caroliniana (Kaul \& Kaul, 2012), Aspidosperma quebracho-blanco (Lin \& Bernardello, 1999), Begonia involucrata (Agren \& Schemske, 1991) and Begonia gracilis (Castillo, Caballero, Boege, Fornoni, \& Dominguez, 2012).

Flowers are often visited by a number of insect species, however, a mere floral visitor of a plant is not essentially its pollinator. In addition to effective pollinators, often there are illegitimate visitors which take nectar or pollen from a flower without pollinating it. These are referred to as nectar or pollen thieves, respectively (Inouye, 1980; Endress, 1994).

Clerodendrum indicum (L.) O. Kuntze (Lamiaceae) is well known for its ethnomedicinal properties (Kirtikar \& Basu, 1935; Chopra, Chopra, Handa, \& Kapur, 1958). A number of bioactive compounds have been detected in this sparsely branched shrub (Srivastava \& Patel, 2007). The species is reported to be distributed widely in South East Asia including India, Southern U.S., W. Indies and Venezuela (Hooker, 1885; Rajendran \& Daniel, 2002). However, a recent survey in West Bengal reveals that the wild populations are quite rare in the region, indicating that the species is becoming threatened regionally, thereby necessitating its conservation. As the knowledge of pollination ecology of a species is an important priority for its conservation, studies on pollination ecology of $C$. indicum, which was hitherto unknown, was undertaken.

\section{MATERIAL AND METHODS}

Clerodendrum indicum is a semi-woody perennial, up to $4.5 \mathrm{~m}$ tall. The present work is based on 118 plants occurring in three widely separated wild populations at Amarun $\left(23^{\circ} 21^{\prime} 57.6^{\prime \prime} \mathrm{N} \& 7^{\circ} 56^{\prime} 9.6\right.$ " E) and Krishnapur $\left(23^{\circ} 15^{\prime} 50.4^{\prime \prime} \mathrm{N}-87^{\circ} 51^{\prime} 32.4\right.$ " E) villages of Burdwan District and Rambhadrapur Vil-

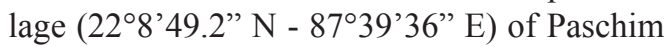
Midnapur District of the state of West Bengal in India (Fig. 1), together with 25 individuals grown in the experimental plot of Botany Department, Burdwan University. In the experimental research plot, the plants were grown on untreated natural soil in open air. Altogether 25 plants were grown in five rows, two metres apart and five plants in each row at an interval of two metres.

Flowering phenology, flower production and floral display size: Day to day flower production by 20 individuals in each of the three wild populations was recorded in each year during the three consecutive years (20122014). Finally, floral display size of an individual was deduced and the flowering strategy of the species was determined following the terminologies of Gentry (1974).

Flower structure and floral events: Details of floral biology including the flower structure and floral events (flower opening, anther dehiscence, stigma receptivity and floral longevity) were studied with a 10x high resolution hand lens (IRL), a Leica WILD M3B Stereo-binocular microscope (Switzerland) and a Leica DMLB compound bright field light microscope (Germany). Each observation was based on a total of at least 50 flowers belonging 


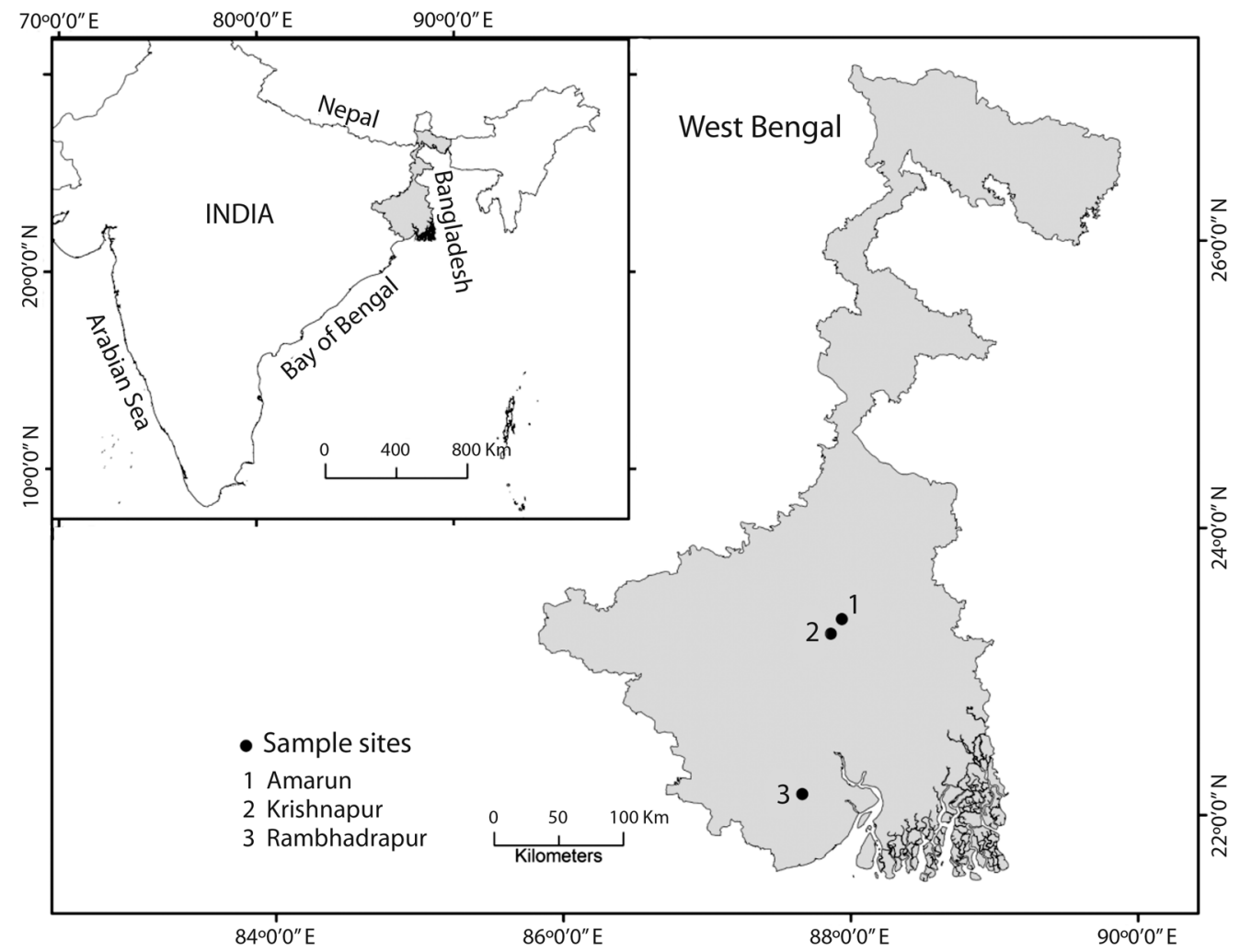

Fig. 1. Map of Southern part of the state of West Bengal in India showing the sites of occurrence of natural populations of Clerodendrum indicum at Amarun, Krishnapur and Rambhadrapur villages.

to ten different individuals. The 'closed vial test' was performed to detect the presence of olfactory attractants (if any), as per the methodologies of Faegri and van der Pijl (1979). Glandular tissues in the flower were identified initially by apparent secretion and subsequently confirmed by positive reaction with neutralred staining (Esau, 1965). A $0.05 \%$ aqueous solution of the stain was used and specimens of whole flower were kept immersed in the stain for about ten minutes, followed by thorough washing in distilled water. To ascertain the presence of soluble sugar in the secretion, anthrone test was performed (McCready, Guggolz, Silviera, \& Owens, 1950). The secretion accumulated in the calyx cup was collected by capillary tube and dissolved in equal volume of distilled water. Freshly prepared anthrone solution (two grams of anthrone reagent dissolved in one litre of cold $95 \% \mathrm{H}_{2} \mathrm{SO}_{4}$ ) was added to the material in 3:1 proportion and kept in icebath for half an hour.

Pollen production and pollen dispersal: Pollen production was estimated by direct counting method (Cruden, 1977). One anther was removed from a fully mature flower bud just before anther dehiscence. The anther was gently squashed on a slide, covered with a 22 x $50 \mathrm{~mm}$ cover slip and the pollen grains were counted under 10x objective of a compound microscope. Determination of mean value was based on ten anthers collected from 25 tagged flowers belonging to five different individuals. Finally, the value was multiplied by four (number of anthers in a flower) to determine the total number of pollen grains produced per flower. To record the percentage of pollen dispersal through time since anther dehiscence, pollen contents in dehisced anthers were counted 
at regular intervals of one hour each through the entire phase of pollen dispersal. Estimation of each hour was based on ten anthers from ten tagged flowers belonging to five different individuals. Finally, the percentage of pollen dispersal was calculated on the basis of the mean value of initial pollen content in an anther as deduced during the study of pollen production. The work was done in each month of two flowering seasons of the species in a calendar year, once during May-June and again during September-October. The work was repeated in three consecutive years, during 2012 to 2014.

Stigma receptivity: Attainment and duration of receptivity of stigma were ascertained by studying the morphological changes in stigma by in vivo pollen germination experiments and dehydrogenase activity through Hydrogen Peroxide Test (Zeisler, 1933; Galen \& Plowright, 1987). The duration during which pollen deposition over the stigma takes place was ascertained by examining excised stigmas at two hours interval all through the floral longevity (Kearns \& Inouye, 1993).

Visitors and pollinators: An entire inflorescence, rather than individual flowers, represents a blossom with respect to pollinator attraction. Therefore, the observations on visitor incidence were based on ten inflorescences belonging to five different individuals. The time of incidence of insects was recorded through the floral longevity in each month of both the flowering seasons and the work was repeated in three consecutive years (20122014). The activity of visitors in and around an individual flower was observed in minute detail, with unaided eyes and also by using a 10x hand lens. The floral visitors were captured with a hand net at different times of the day in each of the two flowering seasons. Altogether 226 specimens were collected. Specimens of each insect species were preserved dry as well as in $70 \%$ alcohol and were identified with the help of entomologists at Zoological Survey of India, Kolkata. Insect-visitors were carefully studied under a Stereo-binocular microscope to detect the presence of pollen (if any) on their bodies and position of pollen deposition. To identify the pollen grains adhering to the bodies of the visitors, adhered pollen grains after removing from the body of the visitors with the help of a fine brush, moistened with sterile distilled water, were mounted in $50 \%$ glycerine and observed under a bright-field microscope. Among the visitors, potential pollinator was identified if the following pollination postulates were fulfilled: i) coincidence of the visitation with the duration of anthesis, ii) while visiting a flower, chance of the visitor to come in contact with the pollination organs i.e. the dehisced anthers and receptive stigma, iii) adherence of pollen grains to the body of the visitor, iv) role of the visitor in pollen deposition over conspecific stigma in controlled pollination experiment. Controlled pollination experiments by bagging were performed to ascertain whether any pollen deposition could occur in the absence of visitors (Kearns \& Inouye, 1993). Flowers were bagged with pieces of fine nylon net preventing insect visitation. The stigmas of such flowers were examined at the end of third day with a Stereo-binocular microscope to detect the presence of any deposited pollen. The observations were based on 25 tagged flowers belonging to five different individuals of the population of Krishnapur locality in each of the two flowering seasons.

Field photographs and photomicrographs were taken by a Nikon D5000 SLR camera and a Leica DFC295 camera, respectively.

\section{RESULTS}

Flowering phenology: Clerodendrum indicum flowers twice a year, in May-June and again in September-October (Fig. 2A). Therefore, with respect to its flowering strategy the species can be regarded as a 'cornucopia' one.

Flower production and floral display size: In $C$. indicum, moderate sized creamishwhite flowers are produced in large $( \pm 0.6 \mathrm{~m}$ long), showy, terminal panicle of 3-15 flowered dichasial cymes (Fig. 2B). A plant, in its first 


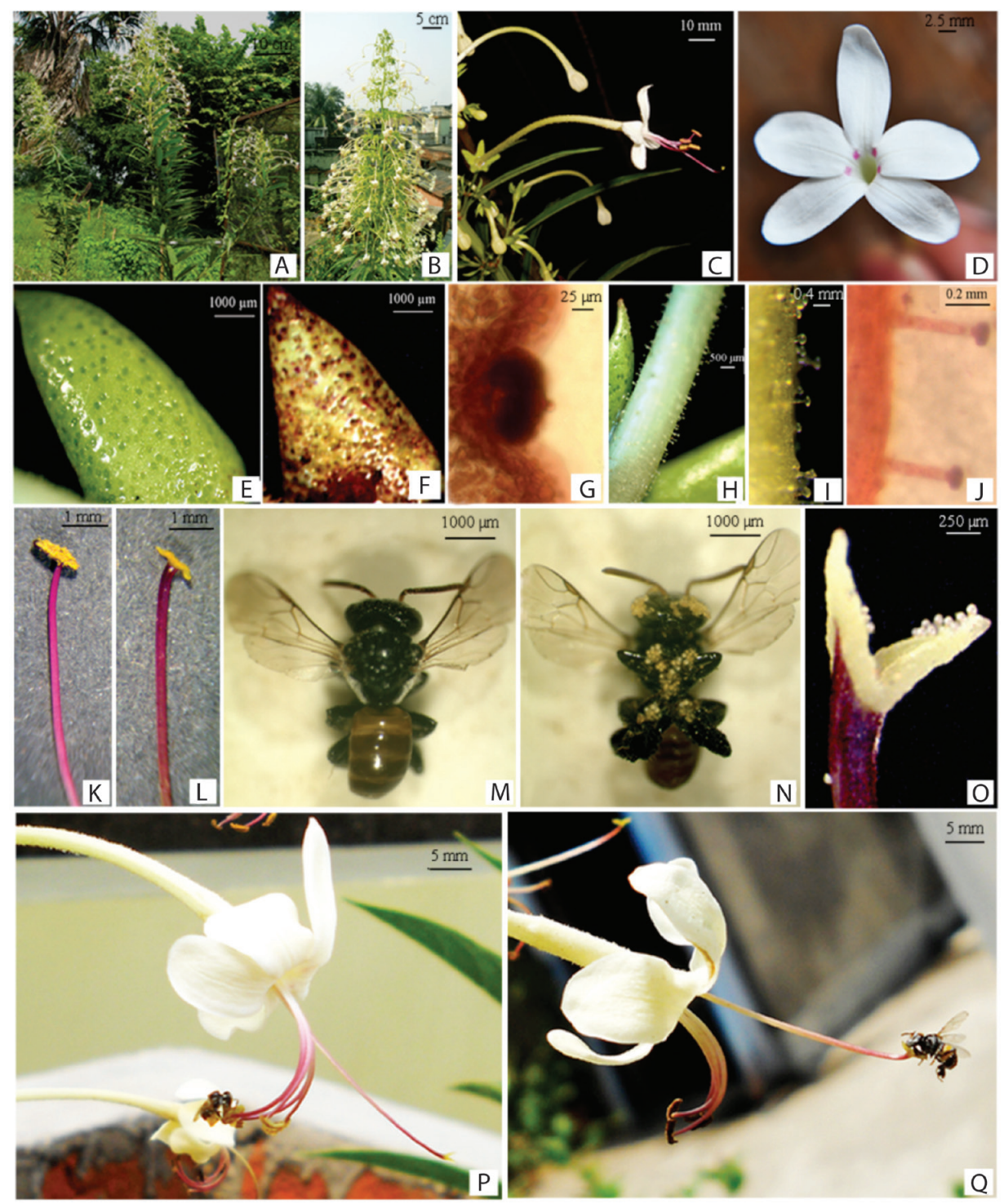

Fig. 2. A. A few individuals of Clerodendrum indicum in their natural habitat, showing flowering twigs B. Terminal panicle with a mass of creamish-white flowers. C. Part of the inflorescence of $C$. indicum showing a few flower buds at different stages of development and an open flower exhibiting calyx with its light green, lanceolate lobes, creamish-white corolla with a slender corolla-tube terminating into five free lobes, the exposed parts of four stamens and the distal part of style terminating into a bifid stigma. D. Ventral side of an excised corolla-disc, magnified, showing prominently the four bright pink spots. E. The scabrate ventral surface of calyx-lobe exhibiting uniformly distributed, closely-spaced shallow depressions (cushion nectaries). F. Ventral surface of a calyx-lobe after neutral red staining. G. Ventral surface of a calyx-lobe magnified, showing an elevated dome-like structure in the centre of a shallow depression. H. Dorsal surface of corolla-tube, showing sparsely distributed glandular hair (trichome nectaries). I-J. Magnified view of the glandular hair before and after neutral red staining. K. A fully dehisced anther terminating a reddish pink filament. L. Stigma of a flower in its receptive phase, strikingly mimicking the dehisced anther; the reddish pink terminal part of the style exhibiting close resemblance to the filaments of stamens with dehisced anthers. M. Dorsal view of a specimen of Trigona sp. N. Ventral view of Trigona sp. showing sternotribically (underside of its body) adhered masses of pollen grains. O. Pollen load on a receptive stigma left in open-pollinated condition. P. An individual of Trigona sp. avidly collecting exposed pollen mass of the dehisced anthers of a $2^{\text {nd }}$ day flower. Q. An individual of Trigona sp. exploring the receptive stigmatic lobes of a $3^{\text {rd }}$ day flower. 
year of flowering, remains unbranched and produces a single terminal panicle. In subsequent years, with age, due to gradual increase of lateral branches, the number of terminal panicles also gradually increases. Therefore, daily flower production and floral display size of the species varies widely with the age of the individual. A panicle produces $48 \pm 2.83$ flowers per day and altogether $308.4 \pm 32.83$ flowers throughout its life.

Floral architecture: 'Closed vial test' revealed that flowers of $C$. indicum are odourless, at least to humans. Flowers are tubular (Fig. 2C). The persistent, campanulate, gamosepalous calyx is comprised of five light green sepals, proximally fused up to $\pm 2 / 5^{\text {th }}$ (5-6 mm) of their length with distal ends \pm $3 / 5^{\text {th }}$ free from each other. Distal free lobes of the calyx are lanceolate, 7-9 $\mathrm{mm}$ long and 4-5 mm wide and outwardly reflexed at an angle of $\pm 60^{\circ}$ with the floral axis. Shallow depressionlike glands are present on the ventral surface of the calyx (Fig. 2E). Each of the depressions at its centre has an elevated dome-like structure bearing a tiny conical projection on top (Fig. $2 \mathrm{G})$. In mature flower bud as well as during the open flower phase, an apparent secretion has been noticed to take place in the depressions. The secretion accumulates as thick slimy white exudates in the calyx-cup. The specific tissue responsible for such secretion was ascertained by neutral-red staining of the intact calyx (Fig. 2F). The central dome of the depression acquired the red colour indicating its secretory nature (Fig. 2G).

The creamish-white, gamopetalous corolla is composed of five petals which are proximally fused forming a 80-92 $\mathrm{mm}$ long and 2.0$2.5 \mathrm{~mm}$ wide, slender corolla-tube and distal five lobes, free from each other (Fig. 2C). The corolla-lobes exhibit a little variation among themselves with respect to their shape and size, thereby imparting a slight zygomorphy to the floral symmetry. The two posterior lobes are obovate, $12-13 \mathrm{~mm}$ long and 6-7 $\mathrm{mm}$ wide. The two lateral lobes are also somewhat obovate in shape, but a little wider than the posterior ones, measuring $12-13 \mathrm{~mm}$ in length and 7-8 $\mathrm{mm}$ in width. The anterior lobe, the largest one, is lanceolate, 14-16 $\mathrm{mm}$ long and 6-7 mm wide (Fig. 2D). A bright-pink spot is present near the corolla-throat at each junction between two adjacent corolla-lobes except that between the two posterior lobes (Fig. 2D). Thus, altogether four such spots are present in a flower which forms a sharp contrast against the creamishwhite background. Sparsely distributed fine glandular hair is present on the dorsal surface of the corolla (Fig. 2H). Each hair is multicellular and uniseriate with a globular, knoblike terminal cell and is Neutral-red positive with copious secretions during the $1^{\text {st }}$ and $2^{\text {nd }}$ day of flower opening (Fig. 2I and Fig. 2J). However, no such secretion was noticed in a $3^{\text {rd }}$ day flower.

Stamens are four in number, epipetalous and didynamously disposed (Fig. 2C). The free parts of the filaments of the shorter pair of stamens are 24-26 mm long, projecting the terminal anthers 14-16 mm beyond the throat of the corolla-tube. Filaments of the longer pair of stamens are 30-32 mm long with anthers projecting 20-22 $\mathrm{mm}$ beyond the throat of the corolla-tube. Free parts of the filaments are slender, hollow, less than $0.5 \mathrm{~mm}$ wide and rather stiff in nature. The portion of each filament projecting beyond the corolla-tube is reddish pink in colour and the portion within the corolla-tube is creamish white in colour. Anthers are 2.5-3.0 mm long and 1.0-1.5 $\mathrm{mm}$ wide, dorsifixed, reddish pink in colour, bilobed and tetralocular with dehiscence-slit facing the interior of the flower (introrse).

Ovary is superior, light green in colour, dome shaped, 1.5-2.5 mm wide and 1.5-2.0 $\mathrm{mm}$ in height, outwardly 4-lobed and internally 4-chambered with incomplete wall-partitions. Each chamber has with a solitary, hemitropous ovule on an axile placentum. The style is slender, hollow, 115-120 mm long and $0.5 \mathrm{~mm}$ wide and somewhat stiff in nature. The part of the style that remains within the corolla-tube is creamish white in colour and the distal part (30$32 \mathrm{~mm}$ ) beyond the corolla-tube is reddish pink in colour. Stigma is bifid, each lobe somewhat 
spathulate, $1.0 \mathrm{~mm}$ long and $0.5 \mathrm{~mm}$ wide. In a freshly bloomed flower, the stigmatic lobes are light green in colour. Stigma is of dry-type with papillate receptive surface.

Floral phenology: Individual flowers of $C$. indicum have four-day longevity. Flowers open in late afternoon (04.30-06.20 pm) and anthers dehisce almost simultaneously with corolla opening. An anther produces 1619.6 \pm 74.182 pollen grains. Although anther dehiscence takes place on the $1^{\text {st }}$ day of flower opening, a very small amount of pollen i.e., $7.7 \pm$ $0.41 \%$ is seen to be dispersed from the anthers on that day, as deduced from the pollen count of the dehisced anthers on the $2^{\text {nd }}$ day morning. The bulk of the pollen i.e., $89.64 \pm 0.91 \%$ is dispersed from morning till the afternoon of the $2^{\text {nd }}$ day of flower opening and the anthers become almost empty by $03.00-05.00 \mathrm{pm}$ of that day (Fig. 3). On the $3^{\text {rd }}$ day early morning (05.00-05.45 am) the stigmatic lobes reach an angle of $\pm 180^{\circ}$, simultaneously attaining a shiny, lustrous appearance (Fig. 2L). The stigma acquires its true receptivity at around this time, which continues till the afternoon (03.30$04.30 \mathrm{pm}$ ) of that day. The receptive stigma strikingly looks like a freshly dehisced anther of $2^{\text {nd }}$ day flower (Fig. 2K and Fig. 2L). With the progress of various floral events from the $1^{\text {st }}$ through the $3^{\text {rd }}$ day of flower opening, at the early morning of the $4^{\text {th }}$ day $(05.45-07.30 \mathrm{am})$, the corolla becomes slightly yellowish in colour and appears somewhat dehydrated \& pale, indicating the commencement of corolla senescence. Soon a brownish abscission zone becomes apparent at the base of the corollatube. However, the corolla persists more or less at this state for rest part of the $4^{\text {th }}$ day and floral longevity is physically ceased by the abscission of the corolla in the early morning (04.00-05.30 am) of the $5^{\text {th }}$ day from flower opening.

Floral events in the species are more or less synchronous not only in an individual but also in populations of a region. The timing of a floral event was noticed to vary by a maximum of $45 \mathrm{~min}$ among the flowers of an individual and by $1 \mathrm{hr} 50 \mathrm{~min}$ among the flowers belonging to different individuals of a population of 62 plants (in Rambhadrapur locality) (Fig. 4). In view of the four-day longevity of individual flowers, such variations in timings of floral events can be regarded insignificant.

Floral visitors: Ten species of insects belonging to the orders Hymenoptera (three species), Diptera (two species), Coleoptera (two species), Lepidoptera (two species) and Orthoptera (one species), were found to regularly visit the flowers of $C$. indicum (Table 1). With respect to their time of visit, activities during visit and adherence of pollen grains to their bodies, visitor species can be classified into following three distinct categories:

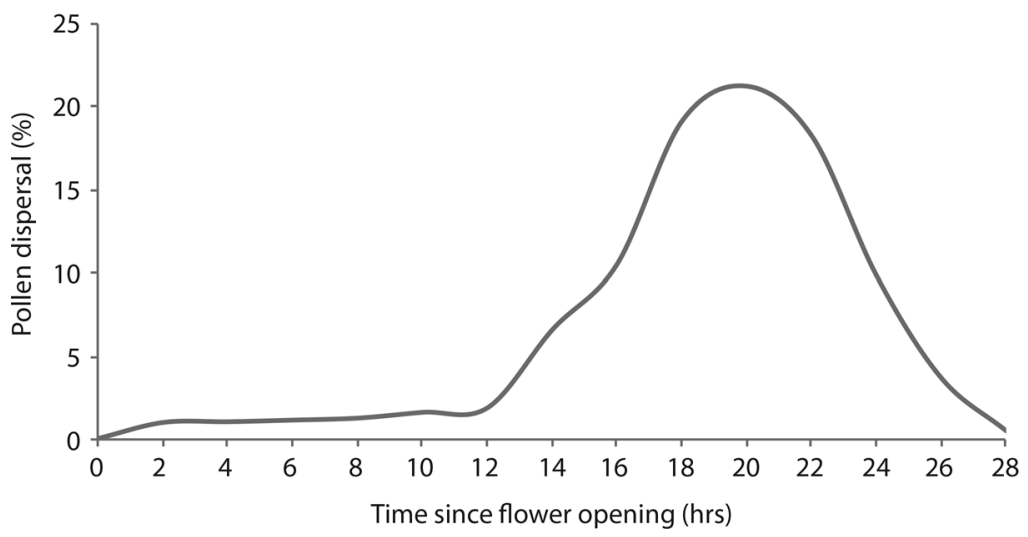

Fig. 3. Graphical representation of hourly pollen presentation from dehisced anther through time since flower opening in Clerodendrum indicum. 


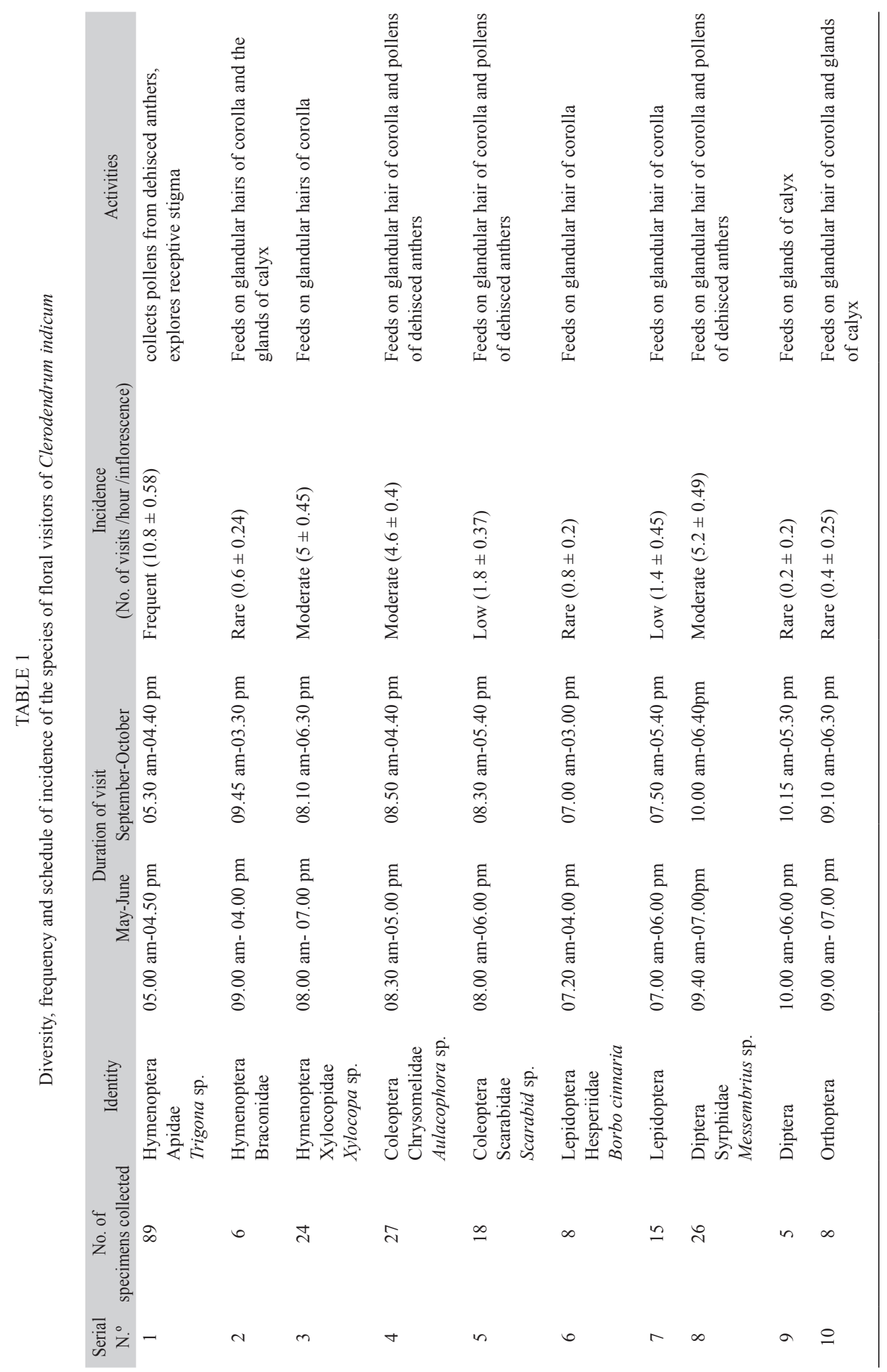




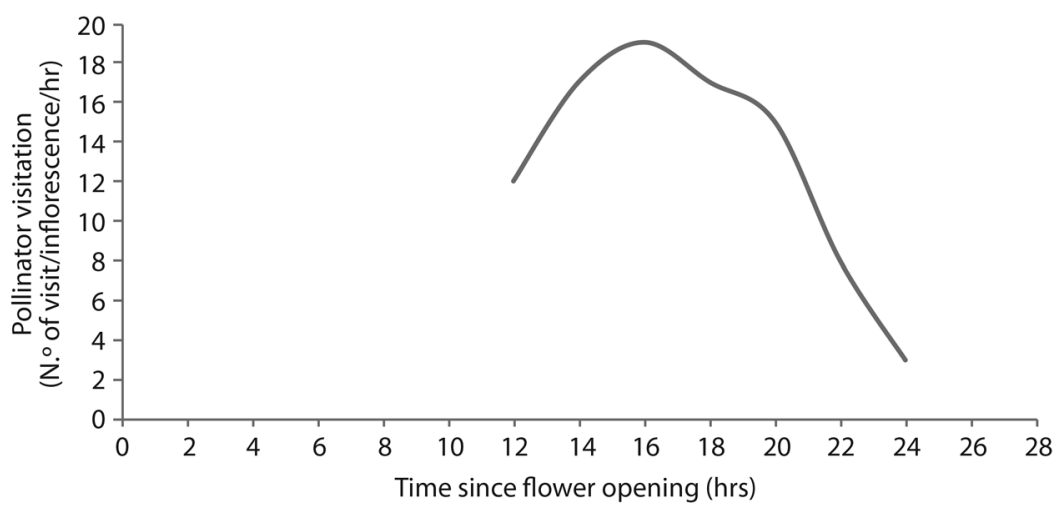

Fig. 4. Pollinator visitation rate (number of visits per inflorescence per hour) with progress of time since flower opening in Clerodendrum indicum.

Category-I: One hymenopteran member (visitor-2) (Fig. 5B), Xylocopa sp. (visitor-3) (Fig. 5C), Borbo cinnaria (visitor-6) (Fig. 5F), one dipteran member (visitor-9) (Fig. 5I) and an orthopteran member (visitor-10) (Fig. 5J) belong to this category. These visit only the $2^{\text {nd }}$ day flowers and their incidence is moderate to rare. While visiting the flowers, some of them (visitor-2, 10) are seen to feed on glandular hair on the corolla-tubes and corolla-lobes and on the glands of the calyx. The rest of them explore either the corolla (visitor-3, 6) or the calyx (visitor-9). Visitor species of this category, during their visits, neither encounter the anthers nor the stigma.

Category-II: Aulacophora sp. (visitor-4) (Fig. 5D), Scarabid sp. (visitor-5) (Fig. 5E), one lepidopteran member (visitor-7) (Fig. 5G) and Messembrius sp. (visitor-8) (Fig. $5 \mathrm{H}$ ) belong to this category. Members of this category are seen to visit sporadically only $2^{\text {nd }}$ day flowers in moderate to low frequency. While visiting the flowers, these sit on corolla-tubes and corolla-lobes, feed on glandular hair on the corolla and on the dehisced anthers. The visitor species of this category visit the dehisced anthers of the $2^{\text {nd }}$ day flowers only. They are not seen to visit any $3^{\text {rd }}$ day flower, when the stigma becomes receptive.
Category-III: The species of stingless bee of the genus Trigona (visitor-1) (Fig. 5A, Fig. $2 \mathrm{M}$ and Fig. $2 \mathrm{~N}$ ) belongs to this category. Individuals of this species are found to dominate the visitor population and visit the flowers of C. indicum most frequently in both the flowering seasons. They visit since early morning till the afternoon and are observed to collect pollen grains from dehisced anthers of $2^{\text {nd }}$ day flowers and explore actively the receptive stigmas of the $3^{\text {rd }}$ day flowers.

\section{DISCUSSION}

The tubular floral construction of Clerodendrum indicum is suitable for melittophilous pollination. The flower is also provided with means for discrimination of illegitimate visitors. Flowers are odourless and floral visitors are perhaps attracted by visual means. The masses of creamish-white flowers, when in full bloom, on large terminal panicles serve as the effective long-distance visual attractant. The four bright-pink spots on the creamish corolla throat perhaps serve as short-distance attractants for visitors in proximity and therefore, can be presumed to function as 'anther guides'. Also, in a $2^{\text {nd }}$ day flower, the dehisced anthers with masses of yellow pollen grains and reddish pink colour of the distal part 

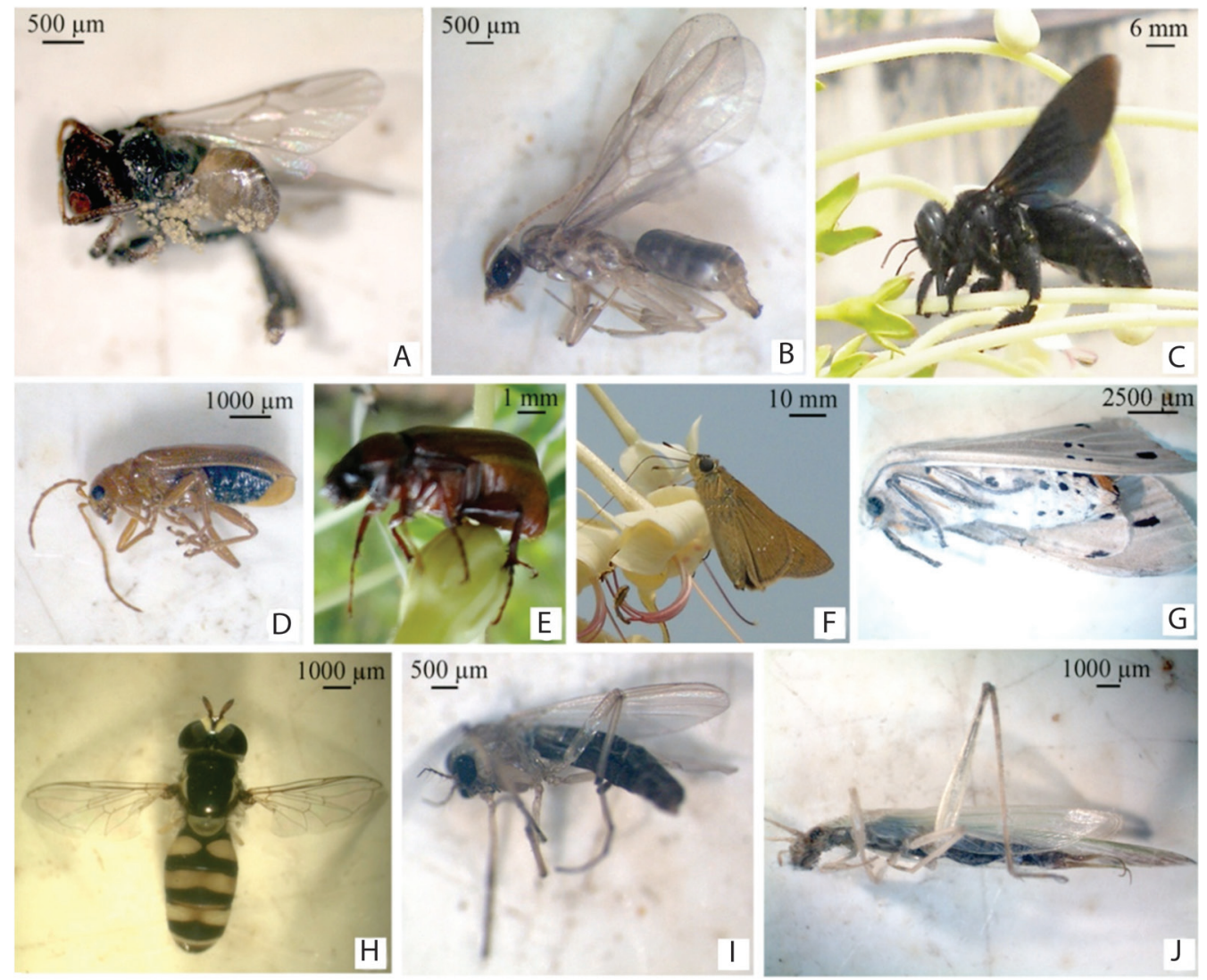

Fig. 5. Floral visitors of Clerodendrum indicum: A. An individual of Trigona sp. (visitor-1) in lateral view. B. A braconidaeous hymenopteran (visitor-2) in lateral view. C. Lateral view of an individual of Xylocopa sp. (visitor-3) visiting upon the corolla-tube. D. Nearly ventral view of an individual of Aulacophora sp. (visitor-4). E. Nearly ventral view an individual of Scarabid sp. (visitor-5) sitting on a mature flower bud. F. Lateral view of an individual of Borbo cinnaria (visitor-6) sitting on the corolla-lobe. G. Nearly ventral view of a lepidopteran species (visitor-7). H. Dorsal view of an individual of Messembrius sp. (visitor-8). I. Lateral view of a dipteran species (visitor-9). J. An orthopteran member (visitor-10) in lateral view.

of the filaments function as short-distance attractants. The yellow, shiny, lustrous receptive stigma of a $3^{\text {rd }}$ day flower strikingly mimics the freshly dehisced anthers of a $2^{\text {nd }}$ day flower. The distal part of the style is reddish pink in colour resembling the distal part of anther filament, which remains projected beyond the corolla-tube. Such an anther-mimicking stigma with reddish pink terminal part of the style also functions as a short-distance attractant.

The exudates from the dome-like glands situated in the shallow depressions on the ventral surface of calyx and the fine multicellular, uniseriate glandular hair on the dorsal surface of corolla are anthrone-positive, indicating its sugary nature. Therefore, structurally those represent cushion and trichome nectaries, respectively as are known to occur in Nepenthes and Abutilon (Daumann, 1930; Vogel, 1977). Edible pollen grains and nectar secreted by trichome nectaries of the corolla and cushion nectaries of the calyx constitute the rewards offered to visitors.

Visitor species of category-I, are seen to feed on trichome and cushion nectaries of corolla and calyx, respectively. They encounter 
neither the anthers nor the stigma. Therefore, in no way they can pollinate a flower of $C$. indicum. Hence, these are mere nectar robbers. Visitor species belonging to category-II are noticed to feed on trichome nectaries of corolla and pollen grains of dehisced anthers of $2^{\text {nd }}$ day flowers. However, these visitor species are not seen to visit any $3^{\text {rd }}$ day flower, when the stigma becomes receptive. Therefore, they cannot be considered as pollinators of $C$. indicum, rather may be regarded as nectar and pollen thieves. The visitor species belonging to category-III (Trigona sp.) are seen to visit dehisced anthers of $2^{\text {nd }}$ day flowers and also to explore actively the receptive stigmas of $3^{\text {rd }}$ day flowers. These can be considered as potential pollinators of the plant as these fulfil all the following pollination postulates: i) the duration of pollen dispersal from anthers and pollen deposition on stigma coincide with their time of visitation; ii) during their visit they have been found to explore both the pollination organs, i.e., dehisced anthers and stigmatic lobes that mimic the dehisced anthers; iii) clumps of pollen grains are found adhered to underside of their bodies; iv) no pollen deposition occur on the stigmas of the virgin flowers bagged early in the morning, prior to the arrival of these visitors. Therefore, stingless bee Trigona $\mathrm{sp}$. is the only legitimate pollinator of the plant. The floral nectaries in the species are not seen to be utilised by its effective pollinators, Trigona sp. However, non-pollinating visitors, including pollen thieves, are seen to feed on these nectaries. The exudates lure the non-pollinating visitors away from the anthers to ensure maximum availability of pollen grains to the effective pollinators for pollination. Therefore, the secretory structures can be interpreted as extra-nuptial nectaries, i.e., nectaries not directly involved in pollination (Endress, 1994). Also, the secretion from the cushion nectaries over the calyx accumulates as a thick, slimy, white exudates in the calyx-cup at the base of the corolla-tube. In open flower phase, ants are seen entrapped in these thick, slimy exudates. Therefore, those seem to act as ant barrier, as reported in case of Viscaria vulgaris (Faegri \& van der Pijl, 1979).
Individuals of Trigona sp. not only dominate the visitor populations in both the flowering seasons but also visit the flowers most frequently from early morning (05.00 to 06.00 am) till afternoon $(04.40$ to $04.50 \mathrm{pm})$. Their first arrival is noticed to take place from 05.00 to $05.20 \mathrm{am}$ in the first flowering season and from 05.30 to $06.00 \mathrm{am}$ in the second flowering season. With progress of time, their frequencies of visit steadily increase up to 07.00 to 07.40 $\mathrm{am}$, then remain more or less constant up to 01.45 to $02.10 \mathrm{pm}$ and finally decline gradually through the afternoon.

Individuals of Trigona sp. visit $2^{\text {nd }}$ day flowers with exposed pollen grains in dehisced anthers as well as $3^{\text {rd }}$ day flowers when the stigma attains its receptivity. In a $2^{\text {nd }}$ day flower all the four stamens remain curved backward making their anthers quite close to each other. An insect, while visiting such a $2^{\text {nd }}$ day flower, is seen to hover around the dehisced anthers and also momentarily lands on those or the filaments, all this while, it avidly collects exposed pollen grains. Meanwhile, powdery pollen grains adhere profusely to the underside of its body. Therefore, the means of pollen deposition on the body of pollinator is 'mess and soil' type (Endress, 1994) and transported sternotribically, i. e., underside of the body of pollinator. As the pollen grains adhere directly from all the four anthers to the body of the pollinator, the pollen presentation by the flower is primary and simultaneous (Faegri \& van der Pijl, 1979). While visiting $3^{\text {rd }}$ day flowers, the insects land on the receptive stigma, explore actively the stigmatic lobes for a while before they fly away. In course of such activity, the sternotribically adhered pollen grains are transferred directly from their bodies to the stigma. Individuals of Trigona sp., the only legitimate pollinator of the plant, are neither seen to feed on the nectaries of calyx and corolla nor even seen to encounter those floral parts during their visits. As mentioned earlier, anther dehiscence takes place in late afternoon on $1^{\text {st }}$ day of flower opening and a very small amount of pollen i.e., $7.7 \pm 0.41 \%$ is dispersed from anthers during evening and night of that day. However, 
no pollinator activity is observed in the flowers of $1^{\text {st }}$ day. Moreover, during that time no receptive stigma remains available in the plant; the stigma of a $3^{\text {rd }}$ day flower becomes receptive in the early morning and loses its receptivity by the afternoon of the same day. Therefore, the minor fraction $(7.7 \pm 0.41 \%)$ of pollen which is dispersed from the dehisced anthers in $1^{\text {st }}$ day cannot play any role in pollination; rather it is a mere loss, in all probabilities by wind. Dispersal of the bulk pollen $(89.64 \pm 0.91 \%)$ which takes place during $2^{\text {nd }}$ day of flower opening coincides with the duration of peak pollinator activity.

The results so obtained reveal that the flowers of $C$. indicum get pollinated by deceiving its pollinator. Individual flowers are distinctly dichogamous and protandrous, with a pause of $\pm 12 \mathrm{hrs}$ between the male and female phases. The species is monophilic, being pollinated by a species belonging to a hymenopteran genus Trigona and edible pollen grain is the only reward offered to the pollinator. Pollinators are attracted by $2^{\text {nd }}$ day flowers at their male phase by offering edible pollen grains. However, a $3^{\text {rd }}$ day flower, when its stigma assumes receptivity, is devoid of the reward (pollen grain). Pollinators' visit in such rewardless flowers is ensured by the anther-mimicking stigma. Mistaking the stigmas as dehisced anthers, the lured insects explore those stigmas and inadvertently lead to direct pollen transfer from their bodies to the receptive stigmas. Zoophilous pollination can be visualized in two distinct phases, first is the presentation of pollen by the anthers to the body of the pollinator and second is the transfer of pollen by the pollinator to the receptive stigma. In $C$. indicum, though the pollen presentation to the pollinator by a $2^{\text {nd }}$ day flower is ensured by offering edible pollen grains as a reward, pollen transfer from pollinator to stigma of a reward-less $3^{\text {rd }}$ day flower is achieved by deceit.

Pollination by deceit is known to occur by various means in different species of unrelated flowering plants. Female flowers of Amborella trichopoda use staminodes, which are similar in appearance to the fertile stamens in male flowers (Thien et al., 2003). In Schisandra henryi and $S$. sphenanthera, the unisexual nonrewarding female flower is similar in appearance to the pollen rewarding male flower and uses visual or olfactory cues to attract pollinators (Yuan et al., 2007; Du et al., 2012). Pollen transfer in the reward-less flowers of Orchis israelitica is achieved by mimicking the nectar supplying species Bellevalia flexuosa (Galizia et al., 2005). In Commelina benghalensis and C. caroliniana, the staminodes attract insects by appearing filled with abundant pollen (Kaul \& Kaul, 2012). In non-nectariferous flower of Aspidosperma quebrancho-blanco, pollinator visit is achieved by gregarious flowering, overlapping with a succession of nectar producing species (Lin \& Bernardello, 1999). Like C. indicum, deceit pollination by an anther-mimicking stigma is also known to occur classically in Begonia involucrata and B. gracilis (Agren \& Schemske, 1991; Castillo et al., 2012). However, unlike $C$. indicum, flowers of the above mentioned species of Begonia are unisexual and female flowers attract pollinators by stigmas mimicking the anthers of the rewarding male flowers.

Deceitful pollination by anther-mimicking stigma had been known earlier only in cases of species with unisexual flowers. Therefore, C. indicum is so far the only known species of flowering plants where in a bisexual flower, deceitful visits of pollinators are ensured by the stigma that mimics anthers.

\section{ACKNOWLEDGMENTS}

An INSPIRE Fellowship awarded to one of the authors (A. G.) by the DST, Govt. of India and infrastructure provided by the UGC under the SAP programme [Centre of Advanced Study in Botany] are gratefully acknowledged. The authors are grateful to B. Mitra, Scientist, Zoological Survey of India, for his help while indentifying the floral visitors. The authors are especially indebted to Peter Crane, Yale School of Forestry \& Environmental Studies, for his invaluable comments after critically going through the manuscript. 


\section{RESUMEN}

Ecología de la polinización de Clerodendrum indicum (Lamiaceae): primer informe de la polinización por engaño imitando el estigma en una flor bisexual. Clerodendrum indicum (Lamiaceae) es un arbusto medicinal importante. Hemos estudiado los detalles de la ecología de su polinización hasta ahora desconocida. El trabajo se realizó durante tres años consecutivos 2012-2014, basado en 118 plantas de tres poblaciones silvestres muy separadas en Bengala Occidental, India, junto con 25 individuos cultivados en una parcela experimental. Los detalles de la estructura de las flores y la dinámica de los eventos florales, la producción y la dispersión del polen, los visitantes y los polinizadores, los atractivos florales y las recompensas florales, así como el mecanismo de transferencia de polen han sido estudiados por metodologías estándar con una lente manual de alta resolución 10x (IRL), microscopio estéreo-binocular (M3B, Suiza) y microscopio de campo brillante (Leica DMLB, Alemania). La flor tubular de cuatro días de longevidad atrae a sus visitantes por señales visuales. Las flores son visitadas regularmente por diez especies de insectos. Con base en el comportamiento del visitante, éstos se pueden clasificar en tres categorías distintas, la mayoría pertenecen a la Categoría-I o a la Categoría-II. Visitan solo las flores del segundo día y nunca visitan una flor de 3er día cuando el estigma asume receptividad. Por lo tanto, no se consideran como polinizadores, sino que actúan como ladrones de polen y / o néctar. Estas son discriminadas por ofrecer secreciones de nectarios extra-nupciales de la flor. Las especies de visitantes de la Categoría III, representadas por una especie de Trigona, constituyen el polinizador legítimo de la planta y, por lo tanto, la hacen monofílica. La presentación del polen de la flor bisexual, dicogámica y protándrica ocurre en el 2do día, mientras que el estigma asume su receptividad en el tercer día de la apertura de la flor. La transferencia de polen al cuerpo del polinizador por una flor de segundo día en su fase masculina se logra ofreciendo granos comestibles de polen. Por otro lado, una flor de tercer día en su fase femenina carece de la recompensa (grano de polen). El estigma receptivo brillante amarillo de tal flor simula sorprendentemente las anteras recién abiertas y los polinizadores que son atraídos por tal estigma inadvertidamente transfieren polen en él. $C$. indicum es hasta ahora la única especie conocida de planta con flor en donde la polinización por engaño se produce por mimetismo de anteras en un estigma de una flor bisexual.

Palabras clave: dicogamia, protandria, monofilia, Trigona.

\section{REFERENCES}

Agren, J., \& Schemske, D. W. (1991). Pollination by deceit in a neotropical monoecious herb Begonia involucrata. Biotropica, 23, 235-241.
Castillo, R. A., Caballero, H., Boege, K., Fornoni, J., \& Dominguez, C. A. (2012). How to cheat when you cannot lie? Deceit pollination in Begonia gracilis. Oecologia, 169(3), 773-782.

Chopra, R. N., Chopra, I. C., Handa, K. L., \& Kapur, L. D. (1958). Chopra's Indigenous Drugs of India ( $\left.2^{\text {nd }} \mathrm{ed}\right)$. Calcutta: U. N. Dhur and Sons.

Cruden, R. W. (1977). Pollen-ovule ratios: a conservative indicator of breeding systems in flowering plants. Evolution, 31(1), 32-46.

Daumann, E. (1930). Das Blutennektarium von Nepenthes. Beihefte zum Botanischen Centralblatt. Abteilung, 1(47), 1-14.

Du, W., Huang, L. J., \& Wang, X. F. (2012). Deceit pollination and the effect of deforestation on reproduction in dioecious Schisandra sphenanthera (Schisandraceae) in central China. Journal of Systematics and Evolution, 50(1), 36-44.

Endress, P. K. (1994). Diversity and evolutionary biology of tropical flowers. Cambridge: Cambridge University Press.

Esau, K. (1965). Plant Anatomy. New York: John Wiley \& Sons, Inc.

Faegri, K., \& van der Pijl, L. (1979). The Principles of Pollination Ecology (3 ${ }^{\text {rd }}$ ed.). Pergamon Press, Oxford.

Galen, C., \& Plowright, R. C. (1987). Testing the accuracy of using peroxidase activity to indicate stigma receptivity. Botany, 65(1), 107-111.

Galizia, C. G., Kunze, J., Gumbert, A., Borg-Karlson, A. K., Sachse, S., Markl, C., \& Menzel, R. (2005). Relationship of visual and olfactory signal parameters in a food-deceptive flower mimicry system. Behavioral Ecology, 16, 159-168.

Gentry, A. H. (1974). Flowering phenology and diversity in tropical Bignoniaceae. Biotropica, 6, 64-68.

Hooker, J. D. (1885). The flora of British India. London: L. Reeve.

Inouye, D. W. (1980). The Terminology of Floral Larceny. Ecology, 61, 1251-1253.

Kaul, V., \& Koul, A. K. (2012). Staminal variation and its possible significance in Commelina benghalensis L. and Commelina caroliniana Walter. Current Science, 103(4), 419-425.

Kearns, C. A., \& Inouye, D. W. (1993). Techniques for Pollination Biologists. Niwot, Colorado: University Press of Colorado.

Kirtikar, K. R., \& Basu, B. D. (1935). Indian Medicinal Plants, Vol. III. Allahabad: L. M. Basu. 
Lin, S., \& Bernardello, G. (1999). Flower structure and reproductive biology in Aspidosperma quebrachoblanco (Apocynaceae), a tree pollinated by deceit. International Journal of Plant Sciences, 160(5), 869-878.

McCready, R. M., Guggolz, J., Silviera, V., \& Owens, H. S. (1950). Determination of Starch and Amylose in vegetables. Analytical Chemistry, 22(9), 1156-1158.

Rajendran, A., \& Daniel, P. (2002). The Indian Verbenaceae: a taxonomic revision. Dehra Dun: Bishen Singh \& Mahendra Pal Singh.

Renner, S. S. (2006). Rewardless flowers in Angiosperms and the role of insect cognition in their evolution. In: Waser, N. M., Ollerton, J., (eds) Plant-pollinator interactions: From specialization to generalization. Chicago: University of Chicago Press.

Sprengel, C. K. (1793). Das Entdeckte Geheimniss der Natur im Bau und in der Befruchtung der Blumen. Berlin: Friedrich Vieweg.
Srivastava, N., \& Patel, T. (2007). Clerodendrum and healthcare: an overview-part II phytochemistry and biotechnology. Medicinal and Aromatic Plant Science and Biotechnology, 1(2), 209-223.

Thien, L. B., Sage, T. L., Jaffré, T., Bernhardt, P., Pontieri, V., Weston, P. H., ... \& Dupre, J.-L. (2003). The population structure and floral biology of Amborella trichopoda (Amborellaceae). Annals of Missouri Botanical Garden, 90, 466-490.

Vogel, S. (1977). Nektarien und ihre ökologische Bedeutung. Apidologie, 8, 321-335.

Yuan, L. -C., Luo, Y. -B., Thien, L. B., Fan, J. -H., Xu, H. -L., \& Chen, Z. -D. (2007). Pollination of Schisandra henryi (Schisandraceae) by female, pollen-eating Megommata species (Cecidomyiidae, Diptera) in South-Central China. Annals of Botany, 99, 451-460.

Zeisler, M. (1933). Über die Abgrenzung der eigentlichen Narbenfläche mit Hilfe von Reaktionen. Beihefte zum Botanischen Centralblatt. Abteilung. 1, 58, 308-318. 